\title{
O descaso com o direito fundamental à saúde dos povos indígenas no enfrentamento da pandemia de Covid-19: a consolidação de uma necropolítica no Brasil
}

\author{
The disregard for the fundamental right to health of the indigenous peoples in \\ coping with Covid-19 pandemic: the consolidation of a necropolitics in Brazil
}

\section{Osmar Veronese* Jaqueline Reginaldo de Almeida*}

\section{Resumo}

O artigo tem por objetivo examinar se o descaso do Estado brasileiro com o direito fundamental à saúde indígena representa a consolidação de uma necropolítica contra as populações tradicionais. Para embasar a discussão, em um primeiro momento, faz-se breves apontamentos sobre a trajetória dos índios no Brasil, expondo um cenário de regulares violações de direitos praticadas desde a colonização. Após, aborda-se o direito fundamental à saúde, sua concretização na realidade dos povos indígenas e o subsistema de saúde indígena pátrio. Por fim, debate ações e omissões adotadas pelo poder público no enfrentamento da Covid-19 nas comunidades tradicionais e interpreta o descaso com a saúde indígena como instrumento de consolidação de uma necropolítica a partir da obra de Achille Mbembe. Na metodologia, o estudo valeu-se da técnica de pesquisa bibliográfica, a partir modo de raciocínio dedutivo e dos métodos de abordagem hermenêutico e crítico-dialético. No resultado, diante da persistente reprodução das atrocidades e violências praticadas desde o Período Colonial, foi possível constatar que o descaso com a saúde indígena no contexto da pandemia de Covid-19 consolida uma política de morte sobre os corpos indígenas, legitimada desde a colonização e renovada nos últimos anos.

Palavras-chave: Direito Fundamental à Saúde. Povos Indígenas. Covid-19. Necropolítica.

\section{Abstract}

This study has the aim to explore if the Brazilian State's disregard for the fundamental right to indigenous health represents the consolidation of a necropolitics against the traditional populations. To support the discussion, at a first moment, it is made brief notes on the conjuncture of the Indians in Brazil, exposing a scenario of regular violations of rights, practiced since the colonization. Then, it draws considerations about the fundamental right to health, discusses its materialization in the reality of the indigenous peoples and approaches the country's indigenous health subsystem. Finally, it debates actions and omissions adopted by the public authorities to face Covid-19 in the traditional communities and interprets the disregard for indigenous health as an instrument of consolidation of a necropolitics, based on the work of Achille Mbembe. In the methodology, the study resorted to the bibliographic research method, from the deductive reasoning and the hermeneutic and critical/dialectical approach methods.

Keywords: Fundamental right to health; Indigenous Peoples; Covid-19; Necropolitics.

Doutor em Modernización de las Instituciones y Nuevas Perspectivas en Derechos Fundamentales, pela Universidad de Valladolid/Espanha; Mestre em Sociedade e Estado em Perspectiva de Integração, pela Universidade Federal do Rio Grande do Sul. Professor do curso de Graduação em Direito e do Programa de Pós-Graduação stricto sensu - Mestrado e Doutorado em Direito - da Universidade Regional Integrada do Alto Uruguai e das Missões - URI Santo Ângelo/RS. Procurador da República/ Ministério Público Federal. Responsável pelo projeto de pesquisa "Estado, Constituição, Diferença: olhares críticos sobre a diversidade no constitucionalismo" e líder do grupo de pesquisa "Direitos de Minorias, Movimentos Sociais e Políticas Públicas", com registro no CNPQ, vinculado à linha de pesquisa Direito e Multiculturalismo, do PPG/URI/Santo Ângelo/RS, Brasil. E-mail: osmarveronese@gmail.com

Mestranda em Direito pelo Programa de Pós-Graduação stricto sensu em Direito - Mestrado e Doutorado - da Universidade Regional Integrada do Alto Uruguai e das Missões - URI Campus de Santo Ângelo/RS - Bolsista CAPES/PROSUC, modalidade taxa. Pós-graduada lato sensu em Direito Processual Civil pelo Complexo de Ensino Renato Saraiva - Faculdade CERS. Graduada em Direito pela Faculdade Cenecista de Santo Ângelo - CNEC - (2019). Integrante do Grupo de Pesquisa "Direitos de Minorias, Movimentos Sociais e Políticas Públicas", com registro no CNPQ, vinculado à linha de pesquisa Direito e Multiculturalismo, do PPGD Mestrado e Doutorado em Direito da URI/Santo Ângelo/ RS. Advogada. E-mail: jaquelinereg@hotmail.com 


\section{Introdução}

Desde o início da pandemia de Covid-19, em 2020, o mundo vive desafiadoras crises sanitárias e humanitárias, envoltas por medos, incertezas e sofrimentos. Porém mesmo com uma crise mundial na saúde, considerar que a pandemia igualou todos os seres humanos é cruel, levando em conta as imensas desigualdades sociais, pois é sabido que muitas pessoas sequer têm acesso a condições mínimas de dignidade - como alimento, saneamento básico e acesso à saúde -, desigualdades essas potencializadas pelo contexto vivido. No entanto, uma coisa pode ser pontuada: a pandemia evidenciou a importância da solidariedade, da alteridade e da promoção dos direitos humanos para a construção de um mundo melhor. Observou-se e observa-se, ainda, a negligência e o negacionismo de alguns governos pelo mundo no enfrentamento da pandemia em nome da "saúde" e da economia, expondo as verdadeiras prioridades sociais, e afetando mais diretamente grupos historicamente subjugados e marginalizados.

A conjuntura histórica dos povos indígenas no Brasil é marcada por violência, falta de reconhecimento e extermínio de grupos, o que parece constantemente se repetir ao longo dos anos. Os povos indígenas continuam sendo encarados como entraves ao desenvolvimento econômico - um discurso fortificado no Brasil nos últimos anos. Por conseguinte, a sociedade dominante continua tentando impor sua "racionalidade", seus modos de vida e suas visões de mundo em detrimento das culturas tradicionais, o que provoca, além de contínuas violações de direitos, o estabelecimento de uma política de controle sobre os corpos indígenas. O descaso com a saúde indígena no enfrentamento da Covid-19 comprova a continuidade das violências praticadas desde o contexto colonial, a partir de políticas legitimadas/praticadas pelo próprio Estado. Assim, resta perguntar: a quem interessa ou a que interessa um novo genocídio contra os indígenas?

Nesse horizonte, o presente artigo visa investigar, a partir da obra do camaronês Achille Mbembe, de que maneira o descaso do Estado brasileiro, com o direito fundamental à saúde indígena, representa a consolidação de uma necropolítica ${ }^{1}$ contra as populações tradicionais. Para tanto, inicialmente, o trabalho desenvolve apontamentos sobre a conjuntura dos índios no Brasil, expondo um cenário de regulares violações de direitos, praticadas desde a colonização até os dias atuais. Após, esboça aspectos do direito fundamental à saúde, discute sua concretização na realidade dos povos indígenas e aborda o subsistema de saúde indígena pátrio. Por fim, para responder ao problema proposto, debate ações e omissões adotadas pelo poder público para o enfrentamento da Covid-19 nas comunidades tradicionais e interpreta o descaso com a saúde indígena como instrumento de consolidação de uma necropolítica. Na metodologia, o estudo usa-se da técnica de pesquisa bibliográfica, a partir do modo de raciocínio dedutivo e dos métodos de abordagem hermenêutico e crítico-dialético.

\section{Povos indígenas no Brasil: um cenário de contínuas violações}

Desde o início da colonização do Brasil, os indígenas enfrentam discriminação, marginalização e tentativas assimilatórias, práticas motivadas pela falta de reconhecimento das diferenças culturais e identitárias, e resultado da expansão-imposição de um determinado modo de vida hegemônico. A "conquista" de novos territórios pelos europeus estava ligada aos ideais de dominação, exploração e desenvolvimento econômico. Conforme Souza Filho (2012), os europeus chegaram à América como se estivessem simplesmente expandindo suas fronteiras agrícolas, extraindo riquezas, devastando o solo e substituindo a natureza existente por outra - mais conhecida e dominada por eles. As guerras travadas contra a resistência dos povos tradicionais marcaram-se pela desigualdade de condições e crueldade, dado o conhecimento de instrumentos de guerra pelos europeus, como a pólvora, por exemplo (SOUZA FILHO, 2003).

Para Cunha (1998), um gigantesco número de povos indígenas desapareceu da face da terra em consequência do que se denomina, num eufemismo envergonhado, "o encontro" das sociedades do Antigo e do Novo Mundo. É difícil de precisar a quantidade de índios que viviam no Brasil antes da chegada dos colonizadores (estando esse número na casa dos milhões). Dados levantados por Oliveira e Freire (2006), a partir de estudos de Curt Nimuendaju, apontam a existência de cerca de 1.400 povos indígenas no território, que correspondia ao Brasil do

À luz dos estudos de Achille Mbembe (2018), pode-se dizer que a necropolítica, ou política de morte, consiste em políticas de escravização e extermínio perpetradas contra determinados grupos sociais historicamente marginalizados, em que o próprio Estado, na expressão máxima da soberania, dita quem pode viver e quem deve morrer, criando mundos de morte e cenários de massivas violações de direitos, como será aprofundado no decorrer do artigo. 
descobrimento. Em contrapartida, de acordo com os dados do último censo realizado pelo Instituto Brasileiro de Geografia e Estatística (IBGE), a população indígena do Brasil é de 896,9 mil índios, sendo esse número ainda menor no século passado. Tal genocídio indígena "foi fruto de um processo complexo cujos agentes foram homens e micro-organismos, mas cujos motores últimos poderiam ser reduzidos a dois: ganância e ambição, formas culturais da expansão do que se convencionou chamar o capitalismo mercantil" (CUNHA, 1998, p. 12).

Nesse contexto, a colonização das Américas desconsiderou os conceitos indígenas de territorialidade e investiu contra povos, dividindo grupos, impondo inimizades imaginadas e alianças forçadas (SOUZA FILHO, 2012). Para Gomes (2012), desde 1500, o Brasil e os índios formam uma dupla incombinável, pois a relação entre ambas as histórias é claramente inversa: à medida que o primeiro cresce, o outro decresce. Desde os primeiros contatos, a imagem dos indígenas passou por uma série de construção simbólica negativa, sendo tachados de povos bárbaros, irracionais, sem cultura, desprovidos de fé ou religião; narrativas incorporadas ao imaginário social ao longo do tempo e que se refletem até os dias atuais nas formas de discriminação, preconceito e exclusão.

"O projeto colonial jamais permitiu variações além do que aquelas que fixavam, por princípio, a posição dos povos indígenas como súditos do rei, vassalos em sua própria terra e seres socialmente inferiores aos portugueses" (GOMES, 2012, p. 75). Consoante Dornelles, Brum e Veronese (2017), esse processo de dominação e conquista foi traumático, pois a sobreposição de uma civilização sobre as outras produziu transformações profundas, especialmente no aspecto da imposição cultural, em que os índios se viram obrigados a abdicar de seus usos e costumes em favor da nova cultura dominadora. Como aponta Souza Filho (2003), a subjugação cultural e econômica promovia uma integração forçada, que não oferecia alternativa senão a destruição.

Nessa perspectiva de dominação e imposição, DUSSEL (1993) trabalha o colonialismo como a face oculta da Modernidade. Para o autor latino-americano, a Modernidade tem sua gênese em 1492, quando a Europa se afirma como o centro de uma história mundial que se inaugura quando pôde se confrontar com o seu "outro", controlando-o, vencendo-o, violentando-o e definindo-se, assim, como um ego descobridor, conquistador e colonizador da alteridade constritiva da própria Modernidade. Dessa forma, consoante a Dussel (1993), esse "outro" não foi descoberto como outro, mas foi "en-coberto" pelo eurocentrismo, num processo em que se fez uma projeção do europeu no não-europeu. $\mathrm{O}$ autor reconhece o conceito emancipador racional da Modernidade, mas denuncia um mito irracional de justificação da violência que deve ser superado. Esse cenário pode ser verificado no Brasil, em que os povos indígenas foram encarados como povos a serem civilizados, povos que foram encobertos.

Essas concepções foram incorporadas pelo aparato jurídico-institucional brasileiro por séculos, o que muito contribuiu para a perpetuação de um imaginário social discriminatório. No que se refere à história constitucional brasileira, somente em 1934 a questão dos direitos indígenas ganhou status constitucional. A primeira Constituição do Brasil Império, outorgada em 1824, sequer faz menção aos índios. Mais tarde, foi editada a Lei $n^{\circ} 601$, de 1850, a qual, de forma curiosa, estabeleceu que o Governo deveria reservar as terras devolutas que julgasse necessárias para a "colonização" dos indígenas. E igualmente à primeira Constituição da República de 1891, não houve menção sobre os índios em seu texto. Não obstante, em seu Art. 64, transferiu aos Estados as terras devolutas, o que gerou uma confusão, pois durante algum tempo se concebeu que as terras indígenas como um todo tivessem passado ao domínio dos Estados (CUNHA, 1987).

Em 1910 foi criado o Serviço de Proteção ao Índio (SPI), que marca a transformação do órgão imperial em republicano e o início de uma política indigenista² desvinculada da igreja, mas que manteve, em sua essência, uma ideia de integração dos povos indígenas, ou seja, a mesma expectativa de acabar com as culturas indígenas para assimilá-las à cultura nacional (SOUZA FILHO, 2012). Adiante, como mencionado, a Constituição de 1934 foi a primeira que resguardou direitos indígenas. O Art. 129 da Lei Mãe determinava o respeito à posse de terras em que os indígenas se achassem permanentemente localizados, sendo-lhes, no entanto, vedado aliená-las (vendê-las ou transferi-las). De outro lado, mantendo a linha integracionista, a Constituição de 1934 estabelecia a competência privativa da União para legislar sobre "incorporação dos 'silvícolas'3 à comunhão nacional". A Constituição de 1937, que implementou o Estado Novo, manteve a disposição contida no Art. 129 da anterior Lei Fundamental.

2 Chama-se de política indigenista o conjunto de ações e iniciativas estatais voltadas aos povos indígenas, à preservação de suas culturas, ao reconhecimento e à efetivação de seus direitos.

3 O termo silvícola, que significa aquele que nasce ou vive na selva, foi empregada nas Constituições de 1934, 1937, 1946, 1967, na EC n 1/1969 e no ainda vigente Estatuto do Índio em referência aos povos indígenas. Todavia, a expressão é inadequada, pois difunde uma ideia pejorativa desses povos como "selvagens" ou "primitivos", sublimando que o que faz da pessoa um indígena não é o fato de nascer ou morar em determinado lugar. 
A Constituição de 1946, em seu Art. 216, seguindo as duas anteriores, determinava o respeito à posse das terras permanentemente ocupadas pelos índios, com a condição de não haver transferência. Posteriormente, no período da ditadura civil-militar, a Constituição de 1967 atribuiu a propriedade das terras indígenas à União. Em seu Art. 186 assegurou-se aos índios a posse permanente das terras que habitavam, reconhecendo assim o direito ao usufruto exclusivo dos recursos naturais e de todas as utilidades nelas existentes. Não obstante, permaneceu-se ainda a disposição relativa à incorporação desses povos à dita comunhão nacional ${ }^{4}$. Também em 1967, com a extinção do SPI, foi criada a Fundação Nacional do Índio (Funai), responsável pela política indigenista até os dias atuais. A Emenda Constitucional $n^{\circ}$ 1, de 17 de outubro de 1969, por muitos considerada uma nova constituição, manteve as disposições do texto original de 1967, inovando ao determinar a nulidade e a extinção dos efeitos jurídicos de qualquer natureza que tivessem por objeto o domínio, a posse ou a ocupação de terras habitadas pelos indígenas. Já no ano de 1973 foi editada a Lei $n^{\circ}$ 6.001, o conhecido Estatuto do Índio, ainda em vigor, que apesar de tratar de importantes direitos indígenas, abarca uma visão extremamente integracionista.

Somente com o marco da promulgação da Constituição Federal de 1988, na perspectiva de horizonte democrático, é que ocorre a desinstitucionalização de visões integracionistas e assimilatórias em relação aos povos indígenas, reconhecendo-se o direito à diferença. Consoante retrata Gomes (2012), a Assembleia Constituinte abriuse para a contribuição e participação de índios, do movimento indígena, de antropólogos, de ONG's e associações, o que possibilitou um resultado extremamente positivo para os povos indígenas. A Constituição Cidadã reserva um capítulo para tratar dos direitos indígenas, com dois artigos específicos de muito peso, reconhecendo aos índios sua organização social, costumes, línguas, crenças e tradições, bem como os direitos originários sobre as terras que tradicionalmente ocupam, competindo à União demarcá-las, proteger e se fazer respeitar todos os seus bens. O Art. 231 é aclamado pela virada constitucional de considerar as terras indígenas como advindas de um direito originário (GOMES, 2012), na esteira da teoria do indigenato, proposta por João Mendes Jr no início do século XX.

\begin{abstract}
O texto aprovado avançou significativamente em relação a todo o sistema anterior porque (1) ampliou os direitos dos índios reconhecendo sua organização social, seus usos, costumes, religiões, línguas e crenças; (2) considerou o direito a terra como originário, isto é, anterior à lei ou ato que assim o declare; (3) conceituou terra indígena incluindo não só aquelas necessárias à habitação, mas à produção, preservação do meio ambiente e as necessárias à sua reprodução física e cultural; (4) pela primeira vez, em nível constitucional, admitiu-se no Brasil que existem direitos indígenas coletivos, seja reconhecendo a organização social indígena, seja concedendo à comunidade o direito de opinar sobre o aproveitamento dos recursos naturais e o de postular em juízo; (5) tratou com mais detalhes, estabelecendo assim melhores garantias, da exploração dos recursos naturais, especialmente os minerais, para o que exige prévia anuência do Congresso Nacional; (6) proibiu a remoção de grupos indígenas, dando ao Congresso Nacional a possibilidade de estudo das eventuais e estabelecidas exceções; (7) mas acima de tudo chamou os índios de índios e lhes deu o direito de continuarem a sê-lo (SOUZA FILHO, 2012, p. 90-91).
\end{abstract}

Apesar da importante virada propiciada pela Constituição de 1988, a realidade social vivida deixa claro que o aniquilamento dos povos indígenas ainda não acabou, do contrário, continua ocorrendo, talvez com outros métodos e outras armas, mas com o mesmo ódio e fruto da mesma arrogância gananciosa, como aponta Souza Filho (2012). O que se percebe é uma contínua reprodução das violações praticadas desde a colonização. Em uma primeira análise, a continuidade desse aniquilamento pode ser observada a partir de uma política de invizibilização dos indígenas e de suas demandas, em que o Estado pouco faz para preservar ou efetivar seus direitos, permitindo o esvaziamento do texto constitucional e o massacre das identidades indígenas. Nesse sentido, podem-se destacar as constantes violações territoriais sofridas, seja pela invasão e exploração de terras já demarcadas, seja pela omissão da União em demarcar territórios tradicionalmente ocupados. Essa conjuntura, além de causar morte e violência nas comunidades, é um dos mais graves atentados contra as culturas indígenas, tendo em vista a especial relação do índio com a terra, bem como sua importância na preservação de suas identidades culturais.

A questão da mineração ilegal em terras indígenas, que afetam especialmente os povos de Roraima, Pará, Amazônia e Mato Grosso, também é alarmante. As superestruturas de mineração dos exploradores e a magnitude

4 A expressão comunhão nacional indicava um ideal de homogeneização, de apagamento das diferenças em nome da construção de uma unidade imaginada tipicamente ligada ao conceito originário de nação. 
das devastações provocadas são assustadoras. Além de toda a degradação ambiental, que também afeta na manutenção e reprodução das culturas, essas explorações interferem na própria saúde indígena, em razão da contaminação da água e do solo, bem como da proliferação de doenças trazidas pelos invasores, destruição de patrimônios ancestrais, e escravização e matança de índios. O governo federal não adota medidas efetivas no sentido de coibir tais práticas, pelo contrário, ultimamente tem até incentivado e tentado legitimar essas violações. Um exemplo disso é o PL 191/2020, proposto pelo Executivo Federal, em que se busca regulamentar a exploração econômica de territórios indígenas a partir de práticas como mineração, turismo, pecuária e exploração de recursos hídricos. No mesmo sentido é o PL 490/2007 que busca alterar regras sobre a demarcação de terras e legalizar explorações, aprovado na Comissão de Constituição e Justiça da Câmara dos Deputados, sem a participação ou oitiva das lideranças indígenas.

Outra tentativa de extermínio encontra-se na PEC 187/2016, aprovada na Comissão de Constituição e Justiça da Câmara dos Deputados, em agosto de 2019, que busca regular a exploração de atividades agrícolas em territórios indígenas, além de incluir ressalvas às prerrogativas de inalienabilidade, indisponibilidade e imprescritibilidade dos direitos territoriais indígenas, permitindo a implantação de parcerias agrícola e pecuária entre a Funai e "brasileiros que explorem essas atividades, conforme o interesse nacional, na forma compatível com a política agropecuária". Também merece destaque as tentativas de transferência da vinculação da Funai para o Ministério da Agricultura, chegando ao ponto de o Supremo Tribunal Federal (STF) precisar se manifestar e determinar que a demarcação das terras indígenas deva permanecer no Ministério da Justiça.

Não bastasse tudo até aqui exposto, indispensável destacar a chamada Tese do Marco Temporal, levantada no Parecer Normativo AGU 001/2017, aprovado pela Presidência da República. A partir desse documento, a administração pública federal conferiu efeitos vinculantes às salvaguardas institucionais fixadas pelo STF no caso Raposa Serra do Sol. Todavia, a própria Corte Constitucional deixou claro que a decisão não é dotada de eficácia erga omnes, ou seja, não produz efeitos vinculantes ou frente a todos. A principal violação constante nesse posicionamento é a chamada Tese do Marco Temporal, que reconhece como terras tradicionalmente ocupadas somente aquelas que estavam sob domínio indígena quando da promulgação da Constituição Federal de 1988. A normativa de observância em todos os órgãos da administração federal direta e indireta motivou a suspensão de vários estudos de delimitação e demarcação em andamento, assim como a abertura de procedimentos de revisão de outras inúmeras áreas já reconhecidas. Atualmente, os efeitos do Parecer Normativo estão suspensos por decisão do STF, que julgará a questão de forma definitiva no bojo do Recurso Extradordinário - RE - 1.017.365/SC, e enquanto isso, o Ministério Público Federal apresentou manifestação pela inconstitucionalidade do marco temporal.

Tal tese restringe e viola os direitos assegurados na Lei Fundamental de 1988, legitimando as violências praticadas desde a colonização. Para SOUZA FILHO (2018), o Marco Temporal é uma decretação de morte da comunidade ou povo por ele atingido, é uma violação aos direitos coletivos reconhecidos nacional e internacionalmente. Conforme parecer firmado por Silva (2018), a Constituição de 1988 não trabalha com data certa, pelo contrário, se são reconhecidos os direitos originários sobre as terras tradicionalmente ocupadas, na linha do Art. 231, é porque já existiam antes da promulgação. $\mathrm{Na}$ análise da questão, não se pode desconsiderar que: 1) diante de todo o histórico de desterritorialização enfrentado, inúmeros povos indígenas estavam despojados de seus territórios tradicionais na data de promulgação da Constituição; 2) somente com a Constituição Cidadã os índios foram legitimados a ingressar para juízo em defesa de seus interesses e direitos; 3) até a edição do Código Civil de 2002, os indígenas eram considerados relativamente incapazes à luz do diploma civil anterior. Veja-se que os indígenas foram expulsos de suas terras, impedidos de defender seus direitos e que agora o mesmo Estado que por vezes patrocinou, expressa ou veladamente, essa expulsão, exige a ocupação na data de 5 de outubro de 1988.

De todo o exposto, impossível deixar de perceber que as violações praticadas desde a colonização continuam se reproduzindo, e que a destruição dos povos indígenas, de suas culturas e identidades, ainda são constantes. Infelizmente, todas as disposições constitucionais e internacionais de proteção dos povos indígenas têm pouca efetividade na realidade fática brasileira, conjuntura que precisa ser superada, sob pena do completo extermínio desses grupos. Ainda assim, importa destacar a resistência e a organização dos povos indígenas na cobrança por reconhecimento e efetivação de seus direitos, inclusive perante o Poder Judiciário, em movimento de defesa da autonomia e da autodeterminação. 


\section{Direito fundamental à saúde de povos indígenas}

A saúde é um direito fundamental social de todos os cidadãos e um dever legal do Estado, reconhecido no Art. $6^{\circ}$ e especificado a partir do Art. 196 da Constituição Federal de 1988, garantido mediante políticas sociais e econômicas que visam a redução do risco de doença e de outros agravos, o acesso universal e igualitário às ações e serviços para sua promoção, proteção e recuperação. Mendes e Branco (2015) observam que, enquanto os textos anteriores apenas faziam referências esparsas sobre o tema, a Carta de 1988 foi a primeira Constituição brasileira a consagrar o direito fundamental à saúde. Nas palavras de Agra (2018), o direito à saúde instiga o Estado ao cumprimento das demandas que possam propiciar aos cidadãos uma vida sem comprometimentos físicos ou mentais, tendo uma dimensão ampla que engloba todas as medidas protetivas da integridade da pessoa humana, exigindo medidas de caráter preventivo, com o objetivo de impedir o surgimento de doenças, e medidas de caráter recuperativo, visando restabelecer o bem-estar da população.

Na mesma senda, o conteúdo do direito à saúde depende do que se entende por saúde e do momento histórico estatal no qual se insere tal direito. Concebido sob o olhar individualista, liberal, a saúde corresponde somente à ausência de doenças, vista a partir do resultado (ter ou não a patologia), sem se preocupar com os motivos que deram causa ao surgimento do mal. Mas em uma perspectiva coletiva, a saúde depende das condições de vida comunitariamente compartilhadas (algo profundo nas comunidades indígenas), devendo ser examinada e tratada levando em conta o contexto social, associada às políticas sociais e econômicas. A saúde-doença, a partir dos marcos assinalados, passa a ser entendida como um processo resultante da forma como as pessoas vivem e se relacionam na sociedade, exsurgindo do ter ou não ter acesso à renda, ao trabalho, a terra, à educação, ao lazer, ao emprego, à moradia, ou seja, às condições do humano em seu habitat. Percebe-se, assim, uma mudança de eixo ainda em curso em relação à concepção de saúde, da organização da assistência centrada na doença, para a atenção integral à vida, com prioridade para as ações preventivas. Em sintonia com a proposta de construção de um Estado Social, o direito fundamental social à saúde exige a intervenção estatal, visando diminuir a desigualdade, dando potência ao princípio da igualdade, núcleo do modelo de Estado proposto (VERONESE; VERONESE, 2017).

Todos os entes federados - União, Estados, Distrito Federal e Municípios - têm o dever de cuidar da saúde, tendo em vista a competência comum estabelecida no Art. 23 da Constituição. De acordo com o Art. 198 da Lei Maior, as ações e serviços públicos de saúde integram uma rede regionalizada e hierarquizada, constituindo um sistema único, o Sistema Único de Saúde, SUS, organizado de forma descentralizada, com direção em cada esfera de governo, voltado ao atendimento integral, com prioridade para atividades preventivas, sem prejuízo dos serviços essenciais, assegurando a participação da comunidade (MENDES; BRANCO, 2015). Veja-se que a garantia do direito à saúde está essencialmente ligada à proteção da dignidade humana e do direito fundamental à vida, o que revela necessidade de uma prestação eficaz e adequada.

O direito à saúde integra o rol dos direitos sociais, culturais e econômicos, que compõem a segunda dimensão de direitos fundamentais, inaugurada de forma concreta a partir do século XX, os quais ostentam um caráter positivo, ou seja, exigem prestações ativas por parte do Estado. Muito se discute acerca da eficácia e aplicabilidade das normas definidoras de direitos sociais prestacionais, como o direito à saúde. Conforme o Art. $5^{\circ}$, $\S 1^{\circ}$, da Constituição Pátria, as normas definidoras de direitos e garantias fundamentais têm aplicação imediata. Tal disposição, consoante Sarlet (2018), expressa uma espécie de mandado de otimização ou maximização, estabelecendo ao poder público a tarefa de reconhecer e atribuir a maior eficácia possível aos direitos fundamentais. Nessa perspectiva, hoje prevalece o entendimento de que a saúde é um direito subjetivo e fundamental e não mais um direito enunciado de modo eminentemente programático (SARLET, 2018).

a) O direito à saúde, na condição de direito subjetivo, assume uma dupla dimensão individual e coletiva (transindividual), cabível, portanto, sua tutela jurisdicional individual, inclusive mediante ação proposta pelo Ministério Público (cuidando-se de direito individual indisponível);

b) A responsabilidade do Estado é solidária, abrangendo todos os entes da Federação;

c) Embora em regra o objeto do direito à saúde deva ser estabelecido pelos órgãos politicamente legitimados (Legislativo e Executivo), no sentido de que aos cidadãos é assegurado um acesso igualitário e universal às prestações disponibilizadas pelo SUS, em caráter excepcional, notadamente quando em causa o direito à vida com dignidade, o Estado tem o dever de disponibilizar os bens e serviços correspondentes; 
d) A desproporcional afetação do sistema de saúde e comprometimento da ordem pública (inclusive das diversas dimensões da reserva do possível) deve ser demonstrada pelo poder público (SARLET, 2018, p. 342-343).

Diante das práticas culturais em relação a medicinas tradicionais, o direito à saúde indígena precisa ser garantido a partir de uma perspectiva intercultural, sob pena de assimilação ou imposição cultural. A Constituição de 1988, reconhecendo as organizações sociais indígenas, assegura a efetivação desse direito fundamental de forma especial e diferenciada. Todavia, até 1999 não existia no Brasil um sistema específico e minimamente estruturado de saúde indígena. O Estatuto do Índio, de 1973, limitou-se a estabelecer, em seu art. 54, que "os índios têm direito aos meios de proteção à saúde facultados à comunhão nacional".

No plano internacional, a Convenção 169 da Organização Internacional do Trabalho, OIT, assegura, em seu Art. 25, que o direito à saúde dos povos indígenas deve considerar as suas condições econômicas, geográficas, sociais e culturais, bem como os seus métodos de prevenção, práticas curativas e medicamentos tradicionais. A Declaração das Nações Unidas sobre os Direitos dos Povos Indígenas, aprovada em 2007, em seu Art. 24, também garante o direito ao uso dos medicamentos tradicionais, à manutenção de suas práticas de saúde, bem como o direito de usufruir o mais alto nível possível de saúde física e mental. Por fim, a Declaração Americana sobre os Direitos dos Povos Indígenas, aprovada em 2016, igualmente salvaguarda a concretização do direito à saúde indígena de forma particularizada, conforme disposições do Art. XVIII, cabendo aos Estados a promoção de políticas interculturais nos serviços médicos e sanitários prestados às comunidades indígenas.

Voltando ao contexto brasileiro, em novembro de 1986 foi realizada a $1^{\text {a }}$ Conferência Nacional de Proteção à Saúde do Índio, a qual indicou, conforme Buchillet (2007), a necessidade de implantação de um modelo que garantisse aos índios o direito universal e integral à saúde, a importância de se respeitar as especificidades étnicas, socioculturais e as práticas terapêuticas de cada grupo, bem como a necessidade de se garantir a participação indígena nas políticas públicas de saúde. Assim, entretempo, promulgou-se a Constituição de 1988 e implantado o Sistema Único de Saúde. Até 1991, a política de atenção à saúde dos povos indígenas era executada pela Funai, através das Equipes Volantes de Saúde, criadas em cada delegacia regional (BUCHILLET, 2007). O Decreto $n^{\circ} 23$, de 4 de fevereiro de 1991, transferiu à Fundação Nacional de Saúde a responsabilidade pela saúde das populações indígenas, englobando as etapas de planejamento e as políticas de execução. O Decreto também previa, em seu Art. $4^{\circ}, \S 1^{\circ}$, que as ações e serviços deveriam ser desenvolvidos segundo modelo de organização na forma de distritos sanitários de natureza especial. Assim, em outubro de 1993 foi realizada a $2^{\text {a }}$ Conferência Nacional de Saúde Indígena, que de forma mais concreta contribuiu para a posterior criação de um subsistema específico.

Mais tarde, o Decreto ${ }^{\circ}$ 1.141, de 5 de maio de 1994, revogou o Decreto $n^{\circ}$ 23/1991 e dispôs sobre as ações de proteção ambiental, saúde e apoio às atividades produtivas para as comunidades indígenas. Tal normativa instituiu uma Comissão Intersetorial de Saúde com a participação de vários ministérios relacionados com a questão indígena, sob a presidência do Ministério da Justiça, órgão ao qual a Funai é até hoje vinculada, restituindo a ela a coordenação, a nível nacional, das ações governamentais voltadas à saúde indígena (BUCHILLET, 2007). Entretanto, apesar do modelo instituído, ocorreu uma compartimentalização das ações de saúde, instaurando uma divisão entre as atividades de assistência e de prevenção, em que a Funai tornou-se responsável pelo aspecto curativo e pelo Ministério da Saúde, através da Fundação Nacional de Saúde, Funasa, pelas ações de prevenção em saúde, consoante Buchillet (2007).

A partir do segundo semestre de 1998 e ao longo do ano de 1999, aponta Buchillet (2007), diversas reuniões e discussões a nível regional e nacional lograram reformular a política de assistência à saúde indígena de modo a reverter a crítica situação sanitária em relação a esses povos. No mesmo sentido, Garnelo (2012) observa o fato sobre o reconhecimento de que o modo de vida indígena tem particularidades que devem ser respeitadas e de que o SUS não dispunha de preparo adequado para o atendimento especial, levaram à proposta de organização de um sistema de saúde específico para os povos indígenas. Assim, foi editada a Lei $n^{\circ} 9.836$, de 23 de setembro de 1999, criando o Subsistema de Atenção aos Povos Indígenas no âmbito do Sistema Único de Saúde, conhecida como Lei Arouca, em vigor até os dias atuais.

Destarte, esse subsistema especial de saúde é totalmente custeado pela União, sendo hierarquizado, regionalizado e descentralizado pelos Distritos Sanitários Especiais Indígenas. Com a Lei Arouca, o Ministério da Saúde, por intermédio da Funasa, ficou responsável por coordenar e executar as ações de saúde indígena. Dessa forma, em razão desse órgão federal dispor de pouco pessoal próprio para desenvolver suas tarefas, optou-se por 
subcontratar municípios e organizações não governamentais para a realização das ações de saúde em aldeias onde a Funasa não contasse com rede própria. Além disso, a coordenação nacional do subsistema passou a ser feita pelo Departamento de Saúde Indígena (Desai), um setor da Funasa (GARNELO, 2012).

A Portaria do Ministério da Saúde $n^{\circ}$ 254, de 31 de janeiro de 2002, aprovou a Política Nacional de Atenção à Saúde dos Povos Indígenas. Mais tarde, a Portaria MS n 70, de 20 de janeiro de 2004, aprovou as Diretrizes da Gestão da Política Nacional de Atenção à Saúde Indígena. Em 2010 foi criada a Secretaria Especial de Saúde Indígena (Sesai), também vinculada ao Ministério da Saúde. Com isso, a Funasa deixou de ser responsável pela saúde indígena, passando à Sesai o encargo de coordenar e executar a Política Nacional de Atenção à Saúde dos Povos Indígenas, bem como de gestar todo o Subsistema de Atenção à Saúde Indígena.

O subsistema estabelecido pela Lei $n^{\circ} 9.836$ determina a obrigatoriedade de se levar em consideração a realidade local, as especificidades da cultura dos povos indígenas e o modelo a ser adotado para a atenção à saúde indígena, que se deve pautar por uma abordagem diferenciada e global, contemplando os aspectos de assistência à saúde, saneamento básico, nutrição, habitação, meio ambiente, demarcação de terras, educação sanitária e integração institucional. "Neste sentido, cabe ao Estado não somente disponibilizar serviços médicos para os povos indígenas, mas também proporcionar os meios necessários às comunidades indígenas para melhorar e exercer o controle sobre sua saúde" (BUCHILLET, 2007, p. 8).

O referido subsistema de saúde indígena estrutura suas unidades de ação segundo a proposta dos Distritos Sanitários Especiais Indígenas, que se caracterizam como uma rede interconectada de serviços de saúde, a fim de oferecer cuidados de atenção primária à saúde, adequados às necessidades sanitárias da maioria da população (GARNELO, 2012). Conforme a Portaria do Ministério da Saúde $n^{\circ} 1.801$, de 9 de novembro de 2015, o Subsistema de Atenção à Saúde Indígena (Sasisus), é formado pelos seguintes estabelecimentos: I - Distrito Sanitário Especial Indígena (DSEI); II - Polo Base (PB); III - Unidade Básica de Saúde Indígena (UBSI); e IV - Casa de Saúde Indígena (Casai). De acordo com a normativa, os DSEl's são espaços territoriais, etnoculturais e populacionais, onde vivem povos indígenas e desenvolvem-se ações de atenção básica de saúde indígena e saneamento básico, respeitando os saberes e as práticas de saúde indígena tradicionais, dentro de determinada área geográfica, sob sua responsabilidade, podendo abranger mais de um município e/ou um estado. Conforme informações da Sesai ${ }^{5}$, hoje existem 34 (trinta e quatro) DSEl's no país, divididos estrategicamente por critérios territoriais.

Os Polos Base são subdivisões territoriais dos DSEl's e constituem base para as Equipes Multidisciplinares de Saúde Indígena (EMSI) organizarem técnica e administrativamente a atenção à saúde de uma população indígena adstrita, configurando-se como primeira referência para os agentes indígenas de saúde e saneamento, que sejam atuantes nas aldeias, podendo sua sede estar localizada numa aldeia indígena ou em uma área urbana de município. As Unidades Básicas de Saúde Indígena são os postos estabelecidos nas aldeias, variando a estrutura conforme a quantidade de população nos territórios. As Casas de Saúde Indígena, por sua vez, são responsáveis pelo apoio, acolhimento e assistência aos indígenas referenciados à rede de serviços do SUS para realização de ações complementares de atenção básica e de atenção especializada, sendo destinadas também aos acompanhantes, quando necessário.

Analisando brevemente os dados da Sesai ${ }^{6}$, observa-se que o DSEI Interior Sul, por exemplo, atende uma população de 42.518 indígenas divididos em 199 aldeias, contando com 65 Unidades Básicas de Saúde Indígena, 9 Polos Base e nenhuma Casa de Saúde Indígena. O DSEI Manaus atende 31.911 indígenas divididos em 252 aldeias, contando com 17 Polos Base, 18 Unidades Básicas de Saúde Indígena e 1 Casa de Saúde Indígena. Esses dados disponibilizados pelo governo federal, mas não apresentam informações se todas as unidades de saúde elencadas estão efetivamente funcionando. Veja-se que, a partir de estudos realizados, Garnelo (2012, p. 31) aponta ser recorrente "a informação de que o atendimento à população aldeada é descontínuo e de baixa qualidade técnica, que há elevada rotatividade e/ou falta de profissionais para realizar o atendimento, ao lado da escassez de materiais e equipamentos necessários ao desenvolvimento das ações de saúde".

Apesar da existência de um sistema especial, a efetivação do direito fundamental à saúde indígena ainda sofre com muitas limitações e tentativas de retrocessos. A implementação de políticas de saúde diferenciadas, que efetivamente considerem as práticas culturais e tradicionais, continua sendo uma das principais reivindicações dos

Disponível em: <https://saudeindigena1.websiteseguro.com/coronavirus/dsei/>

Disponível em: <https://saudeindigena1.websiteseguro.com/coronavirus/dsei/> 
povos indígenas. Nos últimos períodos, em vez de o Estado brasileiro aprimorar o subsistema de saúde e concretizar os direitos indígenas de maneira geral, tem atuado em desfavor dessas populações. No início de 2019 , o governo federal cogitou extinguir a Secretaria Especial de Saúde Indígena, proposta abandonada depois de diversos protestos em todo território nacional. Igualmente, o Decreto $n^{\circ}$ 9.759, de 11 de abril de 2019, extinguiu o Fórum de Presidentes de Conselhos Distritais de Saúde Indígena (Condisis), acabando com o controle social e participação democrática na saúde indígena. Outrossim, o Decreto n ${ }^{\circ}$ 9.795, de 17 de maio de 2019, extinguiu o Departamento de Gestão da Sesai e, no que trata da saúde indígena, preconiza a "integração do subsistema ao SUS".

Não bastasse o fim do Programa Mais Médicos, do governo federal, fragilizou ainda mais a saúde indígena no Brasil. Com o fim do programa, conforme o Relatório Violência contra os Povos Indígenas no Brasil (CIMI, 2018, p. 117), a saúde indígena perdeu $81 \%$ do contingente de médicos, um déficit real de 301 , do total de 372 médicos que atendiam à população indígena no país. Todos esses fatos evidenciam a precarização da saúde indígena, algo que se mostra muito grave, tendo em vista que, de acordo com Garnelo (2012), a população indígena historicamente tem condições de saúde bem piores que as da média dos brasileiros não indígenas. Assim, a efetivação do direito à saúde dos povos indígenas não está na margem de discricionariedade do Estado, pelo contrário, constitui um dever primordial diretamente ligado à garantia da própria vida desses grupos.

\section{0 descaso do Estado brasileiro com a saúde indígena no enfrentamento da pandemia de Covid-19: a consolidação de uma necropolítica}

Desde o surgimento do novo coronavírus, o mundo vive uma catástrofe humanitária e sanitária sem precedentes. Em 31 de dezembro de 2019, a Organização Mundial da Saúde (OMS) foi informada acerca da existência de inúmeros casos de pneumonia na cidade de Wuhan, localizada na China, causados por um novo tipo de coronavírus (SARS-CoV-2), até então não identificada em humanos, causador da doença Covid-19. Diante dos surtos em diferentes locais, em 30 de janeiro de 2020 a OMS declarou Emergência de Saúde Pública de Importância Internacional. Mais tarde, em 11 de março de 2020, a Covid-19 foi caracterizada pela OMS como uma pandemia. Desde então, já foram confirmados mais de 185 milhões de casos no mundo ${ }^{7}$.

Conforme informações da Universidade JohnsHopkings ${ }^{8}$, o Brasil, em julho de 2021, é o terceiro país com o maior número de casos no mundo, com mais de 18 milhões de confirmações e mais de 526 mil mortes. Os tristes números refletem a forma de enfrentamento traçada pelo país, especialmente pelo governo federal, destacando-se a questão da deficiência da estruturação do Estado Social brasileiro apresentar-se como longe de ser completamente implementado, considerando os altos custos para os cofres públicos. Compreende-se, então, que os gigantescos casos de corrupção que assolam o país há anos, sem dúvida, limitam diretamente a concretização dos direitos fundamentais sociais e também refletem na atual situação da saúde pública.

Em que pesem tais limitações, é necessário pontuar que a pandemia foi menosprezada e politizada no Brasil, criando-se uma rivalidade imaginada entre medidas de enfrentamento do vírus e a manutenção da economia. Por certo, o contexto vivido tem afetado todos os brasileiros, porém, como observa Santos (2020), as pandemias não matam tão indiscriminadamente quanto se julga. Ou seja, o alto número de mortos obtidos no surto pandêmico é mais "direcionado" aos corpos racializados e sexualizados - corpos vulneráveis - que estão mais vulnerabilizados pelas condições de vida impostas socialmente pela discriminação a que estão sujeitos (SANTOS, 2020).

Nesse sentido, no estudo intitulado Análise de Vulnerabilidade Demográfica e Infraestrutural das Terras Indígenas à Covid-199 , na intenção de contribuir nas ações de contenção e prevenção, pesquisadores levantaram dados sobre o percentual de pessoas idosas nas terras indígenas, a média de moradores por domicilio, a existência de banheiro de uso exclusivo ou sanitário nos domicílios, a rede de abastecimento de água, e a localização da terra indígena em relação aos municípios com disponibilidade de leitos em Unidade de Terapia Intensiva, UTI, apresentando resultados que ratificam uma maior vulnerabilidade, bem como a necessidade de uma singular atenção. Além de continuamente enfrentarem diversas dificuldades na efetivação do direito fundamental à saúde, estudos também apontam que os povos indígenas são vulneráveis a infecções respiratórias agudas e, mesmo fora

\footnotetext{
Conforme informações da Organização Pan-Americana de Saúde (OPAS). Disponível em: <https://www.paho.org/bra/index.php?option=com_cont ent\&view=article\&id=6101:covid19\&Itemid=875>

Mapa Interativo Coronavírus em tempo real: <https://coronavirus.jhu.edu/map.html>.

9 Disponível em: <https://apublica.org/wp-content/uploads/2020/04/caderno-demografia-indigena.pdf>.
} 
de períodos epidêmicos, são umas das principais causas de morbidade e mortalidade nas populações (FIOCRUZ, 2020, p. 4).

Note-se que, segundo estudos da Comissão Econômica para a América Latina e o Caribe (2015), a saúde para os povos indígenas equivale à coexistência harmoniosa dos seres humanos com a natureza, entre eles e com outros seres na busca do bem-estar, articulando elementos físicos, mentais, espirituais e emocionais, tanto sob a perspectiva das pessoas como das comunidades, e envolve componentes políticos, econômicos, sociais e culturais. "Como consequência, o direito à saúde dos povos indígenas deve ser entendido tanto em sua dimensão individual como coletiva, sendo interdependente da realização de outros direitos humanos" (CEPAL, 2015, p. 77). O relatório ainda aponta que a discriminação estrutural, o empobrecimento derivado da desapropriação sistemática de seus territórios, a perda das formas de vida tradicionais, os obstáculos para a participação política e o racismo institucionalizado exercem um forte impacto negativo sobre a saúde dessas populações (CEPAL, 2015,). Assim sendo, diante de todas as violações enfrentadas, não se pode ignorar que a saúde desses povos é constantemente abalada.

Ainda assim, apesar de todas as atrocidades, o Brasil ainda abarca a maior diversidade de povos indígenas da América Latina, com 305 povos, o que evidencia a vasta pluralidade cultural (FILAC, 2020). Essa realidade multicultural é uma enorme riqueza, entretanto, é marcada por um fato incontestável: "gran parte de sus habitantes viven en condiciones de vulnerabilidad extrema, lo que significa, entre otros aspectos, altas tasas de desnutrición, inaccesibilidad a servicios de salud, precariedad de infraestructura" (FILAC, 2020, p. 12), ou seja, conjunturas ainda mais agravadas pela pandemia. Conforme dados da Articulação dos Povos Indígenas do Brasil (Apib) ${ }^{10}$, mais de 56 mil índios já foram contaminados, mais de 1.100 morreram e 163 povos já foram afetados. Todavia, os dados oficiais do governo apontam números menores: cerca de 50 mil confirmados e 732 óbitos ${ }^{11}$.

O que se observa é uma "desatenção especial, além da fragilização do sistema de saúde indígena, que proporciona reclamação da parte dos povos tradicionais sobre o descaso do governo federal no enfrentamento da pandemia de Covid-19, uma espécie de omissão deliberada. Uma das principais questões levantadas pelos indígenas é o ingresso e a presença de garimpeiros, madeireiros e grileiros nos territórios tradicionais, invasores que levam a doença até as comunidades, situações que o poder público nada faz para coibir. Veja-se que as atividades assistenciais foram restringidas pela Funai já no dia 17 de março de 2020, conforme a Portaria ${ }^{\circ} 419$ / PRES. Todavia, medidas concretas de restrição de entrada ou retirada de invasores não foram adotadas. Pelo contrário, o governo parece incentivá-las, em muitos casos.

Por exemplo, durante a pandemia, a Funai editou a Instrução Normativa $n^{\circ}$ 9, de 16 de abril de 2020, que disciplina o requerimento, análise e emissão da Declaração de Reconhecimento de Limites (DRL) em relação a imóveis privados, a qual facilita a invasão de territórios. Conforme a Recomendação $n^{\circ} 13 / 2020$, assinada por 49 Procuradores da República de 26 estados, o Ministério Público Federal, MPF, defende a anulação da referida normativa, pois ela permite, de forma ilegal e inconstitucional, o repasse de títulos de terra a particulares dentro de áreas indígenas protegidas pela legislação brasileira; estabelece indevida precedência da propriedade privada sobre as terras indígenas; e aumenta gravemente os riscos de conflitos fundiários e danos socioambientais ${ }^{12}$. Na mesma linha, segundo manifestação da $6^{a}$ Câmara de Coordenação e Revisão do MPF, a normativa revela-se inconstitucional e ilegal ${ }^{13}$, especialmente em razão de a Funai se exonerar de seu dever constitucional, legal e regulamentar de promover o reconhecimento e defender a posse tradicional indígena, bem como zelar pela propriedade imobiliária da União.

Além disso, de acordo com estudo realizado por Ferreira (2020), em 20 de março de 2020 o Ministério da Saúde reconheceu a transmissão comunitária do novo conoravírus em todo o território nacional. Entretanto, o Informe Técnico $n^{\circ} 4 / S_{\text {Sesai }}{ }^{14}$, datado em 30 de março de 2020, informa que, por não ter sido confirmado casos de transmissão comunitária por Covid-19 nas aldeias indígenas atendidas pelo Sasisus, os DSEl's se encontram no nível de resposta de alerta e em fase de contenção. Em outras palavras, o informe não reconheceu a transmissão comunitária nos territórios indígenas, tendo sido retirada a passagem acerca do Informe Técnico $n^{\circ} 5 /$ Sesai, de

\footnotetext{
Atualização diária dos dados em: <https://covid19.socioambiental.org/>.

Disponível em: <https://saudeindigena.saude.gov.br/corona>.

Mais sobre a atuação do MPF: <http://www.mpf.mp.br/df/sala-de-imprensa/noticias-df/mpf-recomenda-ao-presidente-da-funai-que-anule-imediatamenteportaria-que-permite-grilagem-de-terras-indigenas $>$.

Disponível em: <http://www.mpf.mp.br/pgr/documentos/PGR0016730020202.pdf>.

Documentos SESAI: <https://drive.google.com/drive/folders/1NypkAgVkBQU5ztQ4yWVgh1bgxdiBIBhh>.
} 
8 de maio de 2020. Para Ferreira (2020), não reconhecer a inserção das comunidades indígenas no contexto de transmissão comunitária do coronavírus, declarado para o Brasil desde 20 de março de 2020, tem consequências dramáticas para a saúde dos povos tradicionais brasileiros. A antropóloga enfatiza que a negação da situação de transmissão comunitária no contexto das aldeias indígenas parece operar com a lógica de que as fronteiras das comunidades com a sociedade nacional são bem delimitadas, como se fossem totalmente isoladas de onde a transmissão comunitária está acontecendo, o que não denota a realidade.

Outro cuidado negligenciado levantado por Ferreira (2020) diz respeito aos profissionais de saúde indígena como agentes de transmissão. O primeiro caso de indígena detectado com Covid-19 no Brasil ocorreu no Amazonas, a partir de contato com um médico infectado. Assim, o Informe Técnico $n^{\circ} 4 /$ Sesai recomenda que os profissionais de saúde não façam atendimentos à população indígena no caso de apresentarem sintomas respiratórios. Também se recomenda que os profissionais que residam em municípios com transmissão voluntária e apresentem sintomas respiratórios não realizem atendimentos às populações tradicionais. Veja-se que a suspensão do atendimento foi recomendada somente no caso de apresentação de sintomas, desconsiderando a questão dos assintomáticos, que também podem transmitir o vírus. Assim, somente nos casos de povos indígenas isolados e de recente contato, o Informe Técnico $n^{\circ} 4$ apontou a necessidade de quarentena antes da entrada nos territórios.

Mais um descaso que merece ser apontado é a negativa de atendimento por parte da Sesai a indígenas residentes nas cidades. O Ministério Público Federal no Município de Santarém/PA expediu recomendação requerendo a contabilização nos dados e boletins oficiais da secretaria sobre os dados epidemiológicos relativos à Covid-19 entre os indígenas, na cidade de Alter do Chão/PA. Conforme o órgão, a Sesai se recusa a atender povos e famílias residentes fora de terras indígenas e, durante a pandemia do novo coronavírus, também se nega a contabilizar os casos de Covid-19 na população indígena urbana, o que distorce os dados reais da pandemia em relação aos povos indígenas ${ }^{15}$. Com o início da vacinação, as populações tradicionais foram definidas como prioritárias no plano nacional de imunização. Todavia, os indígenas em contexto urbano, residentes nas cidades ou fora dos territórios tradicionais enfrentam dificuldades para conseguir a vacina.

Em nota pública, divulgada em 5 de junho de 2020, o Ministério Público Federal (MPF) critica o posicionamento do governo federal na garantia da saúde dos povos indígenas no contexto da pandemia de Covid-19, alertando a sociedade da gravidade da situação ${ }^{16}$. Diante de tamanho desprezo com a saúde indígena no enfrentamento da Covid-19, a Articulação dos Povos Indígenas do Brasil, juntamente com vários partidos políticos, propôs a Arguição de Descumprimento de Preceito Fundamental 709 no STF, protocolada em $1^{\circ}$ de julho de 2020 , denunciando todo um conjunto de ações e omissões do poder público que corporificam graves riscos de um genocídio e de extermínio de diversos povos. Conforme dados da petição inicial ${ }^{17}$, o índice de letalidade da Covid-19 entre povos indígenas é de $9,6 \%$, enquanto que entre a população brasileira em geral é de $5,6 \%$.

No dia 8 de julho de 2020, a Corte brasileira deferiu parcialmente as medidas cautelares requeridas na inicial, determinando à União a adoção de várias medidas para a contenção da doença nas comunidades, bem como a proteção da saúde e da vida dos indígenas. Em contrapartida, no mesmo dia, o Presidente da República vetou importantes dispositivos do Projeto de Lei 1142/2020, voltado à proteção das populações indígenas. Dos trechos vetados, destacam-se: a obrigação de o governo fornecer água potável, materiais de higiene e limpeza às comunidades; a garantia de oferta emergencial de leitos hospitalares e de UTI a índios e quilombolas; a liberação de verba emergencial à saúde indígena; e o estabelecimento de facilidades ao auxílio emergencial. De todo o contexto, possível perceber o grave e recorrente descaso do governo brasileiro com a saúde dos povos indígenas, inclusive no sentido de desconsiderar a própria condição humana desses indivíduos.

O cenário evidencia a reprodução de contextos históricos de violências praticadas contra os povos indígenas desde a colonização brasileira. As ações e omissões do poder público na questão da saúde somam-se a outras tantas violações já enfrentadas por essas populações, como aqui já mencionado. Todas essas políticas sobre os corpos indígenas fazem refletir a quem ou a que interessa esse regime de extermínio que há tempos vem sendo

Disponível em: <http://www.mpf.mp.br/pa/sala-de-imprensa/noticias-pa/mpf-recomenda-que-secretaria-de-saude-indigena-contabilize-casos-decovid-19-entre-indigenas-de-alter-do-chao-pa>.

16 Vale a leitura da nota: <http://www.mpf.mp.br/pgr/noticias-pgr/em-nota-publica-mpf-alerta-sobre-descaso-com-a-saude-indigena-durante-pandemiada-covid-1>

17 Disponível em: <https://www.conjur.com.br/dl/adpf-apib.pdf >. 
empreendida? Toda a situação fática parece evidenciar o estabelecimento de uma necropolítica em face dos povos indígenas, que encontra na pandemia de Covid-19 a sua consolidação.

O termo necropolítica foi cunhado por Achille Mbembe, com inspiração nos conceitos de biopolítica e biopoder formulados por Foucault em estudos durante a década de 1970, no qual o autor pressupõe que a expressão máxima da soberania reside no poder e na capacidade de ditar quem pode viver e quem deve morrer. Conforme Mbembe (2018), matar ou deixar viver constituem os limites da soberania, são seus atributos fundamentais. "Ser soberano é exercer controle sobre a mortalidade e definir a vida como a implementação e manifestação do poder" (2018, p. 5).

Analisando o contexto histórico, em que os povos indígenas, suas culturas, identidades, crenças e tradições foram (e continuam sendo) colonizados, encobertos, desumanizados e descartados, pode-se claramente observar inscrições de poder sobre os corpos indígenas, uma espécie de biopolítica e, em última análise, uma política de morte. A biopolítica, como observa Souza (2017, p. 16), promove uma politização da vida ou a conversão da vida em objeto natural de governo, "transformando-a em um recurso natural qualificado para os processos de produção e gestão dos estados e das instituições".

Tendo por base a noção de soberania, a formação do Estado moderno e a racionalização da prática governamental, Foucault investiga como o poder, a partir dos séculos XVII - XVIII, passa a interferir e conduzir a vida humana, ou seja, como a vida biológica passa a se converter em objeto político.

\begin{abstract}
Parece-me que um dos fenômenos fundamentais do século XIX foi, é o que se poderia denominar a assunção da vida pelo poder: se vocês preferirem, uma tomada de poder sobre o homem enquanto ser vivo, uma espécie de estatização do biológico ou, pelo menos, uma certa inclinação que conduz ao que se poderia chamar de estatização do biológico. Creio que, para compreender o que se passou, podemos nos referir ao que era a teoria clássica da soberania que, em última análise, serviu-nos de pano de fundo, de quadro para todas essas análises sobre a guerra, as raças, etc. Na teoria clássica da soberania, vocês sabem que o direito de vida e de morte era um de seus atributos fundamentais. Ora, o direito de vida e de morte é um direito que é estranho, estranho já no nível teórico; com efeito, o que é ter direito de vida e de morte? Em certo sentido, dizer que o soberano tem direito de vida e de morte significa, no fundo, que ele pode fazer morrer e deixar viver; em todo caso, que a vida e a morte não são desses fenômenos naturais, imediatos, de certo modo originais ou radicais, que se localizariam fora do campo do poder político (FOUCAULT, 2005, p. 285-286).
\end{abstract}

Assim, no pensamento de Foucault (1999), o termo biopolítica, como uma chave hermenêutica de compreensão da realidade a partir da Modernidade, tem-se como o poder de expor uma população à morte geral é o inverso do poder de garantir a outra sua permanência em vida. "Se o genocídio é, de fato, o sonho dos poderes modernos, não é por uma volta, atualmente, ao velho direito de matar; mas é porque o poder se situa e exerce ao nível da vida, da espécie, da raça e dos fenômenos maciços de população" (FOUCAULT, 1999, p. 129).

À luz de tais premissas, Mbembe (2018) formula o conceito de necropolítica na perspectiva da questão racial, em que o próprio Estado e a sociedade legitimam e/ou reproduzem uma política de escravização e extermínio dos corpos negros, fatos perfeitamente aplicáveis ao cenário dos povos indígenas do Brasil. Nesse sentido, sua preocupação central é com as formas de soberania cujo projeto central não é a luta pela autonomia, mas a instrumentalização da existência humana e da destruição material de corpos e populações.

Mbembe (2018) relaciona a noção de biopoder de Foucault aos conceitos de estado de exceção e de estado de sítio. Para o filósofo camaronês, em tais instâncias, o poder, que não se limita ao poder estatal, continuamente apela à exceção, à emergência e a uma noção ficcional de inimigo. Na formulação de Foucault, o biopoder parece funcionar mediante uma divisão entre as pessoas que devem viver e as que devem morrer. Tal controle distribui a espécie humana em grupos, subdivide a população em subgrupos, estabelecendo uma censura biológica entre uns e outros, conforme a leitura de Mbembe (2018). Como assinala o autor, qualquer relato histórico do surgimento do terror moderno precisa tratar da escravidão, que pode ser considerada umas das primeiras manifestações da experimentação biopolítica. "De fato, a condição de escravo resulta de uma tripla perda: perda de um 'lar', perda de direitos sobre seu corpo e perda de estatuto político. Essa tripla perda equivale a uma dominação absoluta, uma alienação de nascença e uma morte social (que é expulsão fora da humanidade) " (MBEMBE, 2018, p. 27).

Consoante reflexões do filósofo (2018), as colônias, como instauradoras de terror, são zonas em que a guerra e desordem ficam lado a lado, ou seja, são locais em que os controles e as garantias podem ser suspensos e que a violência do estado de exceção supostamente opera o serviço da "civilização". "Aos olhos do conquistador, 
'vida selvagem' é apenas outra forma de 'vida animal', uma experiência assustadora, algo radicalmente outro (alienígena), além da imaginação ou da compreensão" (MBEMBE, 2018, p. 35). Assim sendo, o direito soberano de matar não está sujeito a qualquer regra nas colônias, podendo o soberano matar a qualquer momento e de qualquer maneira, pois as guerras coloniais são projetadas como a expressão de uma hostilidade absoluta que coloca o conquistador diante de um inimigo absoluto, conforme Mbembe (2018).

Dessa forma, o autor observa que a ocupação colonial em si foi uma questão de apreensão, demarcação e afirmação do controle físico e geográfico, inscrevendo sobre o terreno um novo conjunto de relações sociais e espaciais; o que significou a produção de fronteiras e hierarquias, a subversão dos regimes de propriedade existentes, a classificação das pessoas de acordo com diferentes categorias e a produção de imaginários culturais. "Esses imaginários deram sentido à instituição de direitos diferentes, para diferentes categorias de pessoas, para fins diferentes no interior de um mesmo espaço; em resumo, o exercício da soberania (MBEMBE, 2018, p. 39). De acordo com o autor, soberania aqui significa ocupação, e ocupação significa relegar o colonizado a uma terceira zona, entre o estatuto de sujeito e objeto. Nesse contexto, a soberania passa a definir quem importa e quem não importa, quem é descartável e quem não é, consoante Mbembe (2018).

Todavia, o autor também pontua que não se pode pensar que esses arquétipos ficaram em um passado distante. Para ele, a ocupação colonial tardia difere em muitos aspectos da primeira ocupação moderna, especialmente em razão da combinação entre disciplina, biopolítica e necropolítica. Tais colonizações contemporâneas, de acordo com Mbembe (2018), funcionam a partir de três dinâmicas especificas de formação do terror, quais sejam: fragmentação territorial, acesso proibido a certas zonas e expansão dos assentamentos. "O objetivo desse processo é duplo: impossibilitar qualquer movimento e implementar a segregação à moda do Estado do apartheid" (MBEMBE, 2018, p.43).

Seguindo a perspectiva, também se pode verificar, a partir da colonização brasileira, a gênese de uma política de morte sobre os corpos indígenas, que passa a ser legitimada e praticada pelo próprio Estado, desde o Período Colonial, em nome de um modo de organização desenvolvimentista e de um capitalismo predatório. É como se determinados grupos tivessem sua dignidade humana desconsiderada, sendo excluídos dos ideais da nação. Para ele, uma relação desigual é estabelecida ao mesmo tempo em que é afirmada a desigualdade do poder sobre a vida. "Esse poder sobre a vida do outro assume a forma de comércio: a humanidade de uma pessoa é dissolvida até o ponto em que se torna possível dizer que a vida do escravo é propriedade do seu senhor" (MBEMBE, 2018, p. 29). Assim, o autor propõe a concepção de necropolítica ou necropoder para analisar as várias maneiras pelas quais o mundo contemporâneo age com o objetivo de provocar a destruição máxima de pessoas e criar mundos de morte, formas únicas de existência social em que populações são submetidas a condições de vida que lhes conferem ao estatuto de "mortos-vivos".

Nessa ótica, a necropolítica pode ser compreendida como uma política em que o próprio Estado dita quem pode viver e quem deve morrer, como uma prática em que o Estado, a partir de ações ou omissões, adota políticas de morte em face de determinados indivíduos. Diante do contínuo cenário de violação de direitos, estabelecido desde a colonização e renovado nos últimos tempos, é inevitável reconhecer que o descaso com a saúde dos povos indígenas no contexto da pandemia de Covid-19 evidencia a consolidação de uma política de morte contra essas populações tradicionais, há muito tempo concebida no Brasil. As ações aniquiladoras e as omissões que permitem violações de direitos instauram uma necropolítica sobre os corpos indígenas, bem como a posição do poder público, no enfrentamento da pandemia, deixa transparecer a cruel conveniência de um novo extermínio das comunidades tradicionais. Tal necropolítica se consolida especialmente pelo "deixar morrer", o que tem se mostrado muito conveniente às políticas governamentais atuais e à expansão econômica sobre os territórios tradicionais, considerando que até hoje os índios não são reconhecidos em suas diferenças culturais e identitárias. É uma falta de reconhecimento que leva à aniquilação do outro. É o Estado ditando quem "pode-deve" morrer, ou ainda quem "pode-deve" morrer prioritariamente, tendo em vista o descaso generalizado com a vida dos brasileiros por parte de alguns governantes.

Como Judith Butler (2015) observa, se certas vidas não são qualificadas como vidas ou se, desde o começo, não são concebíveis como vidas de acordo com certos enquadramentos epistemológicos, então essas vidas nunca serão perdidas no sentido pleno da palavra. "Assim, há 'sujeitos' que não são exatamente reconhecíveis como sujeitos e há 'vidas' que dificilmente - ou, melhor dizendo, nunca - são reconhecidas como vidas" (CEPAL, 2015, p. 17). Como leciona Warat (2010), a tutela constitucional dos direitos fundamentais pressupõe que os garantidos 
sejam cidadãos, e não excluídos ou postos socialmente em situação de permanente exceção. Nesse sentido, para o autor, a cidadania não existe se o outro da alteridade é um excluído, pois enquanto existirem excluídos é uma hipocrisia falar em cidadania. "Somente se é cidadão se os outros, se a alteridade que organiza as possibilidades de estar entre nós não está excluída. [...] Falar de cidadania em circunstâncias de exclusão é garantir a persistência de estados de exclusão, que são o lado diabólico de nossas sociedades" (WARAT, 2010, p. 82).

A democracia levanta a obrigação de não se calar diante dessas massivas violações de direitos que levam à morte, bem como as omissões na efetivação dos direitos fundamentais que não são compatíveis com a democracia substancial. Nas lições de Ferrajoli (2014), a constitucionalização rígida dos direitos fundamentais, impondo proibições e obrigações aos poderes públicos, inseriu na democracia uma dimensão substancial no que diz respeito àquilo que não pode ser ou deve ser decidido por qualquer maioria, mudando a relação entre a política e o direito. Assim, é a política que se torna instrumento de atuação do direito, submetida aos vínculos a ela impostos por princípios constitucionais: vínculos negativos, como são aqueles gerados pelos direitos de liberdade que não podem ser violados; vínculos positivos, como são aqueles gerados pelos direitos sociais que devem ser satisfeitos (FERRAJOLI, 2014).

Nessa perspectiva, o reconhecimento das diferenças - o reconhecimento do outro como ser dotado da mesma dignidade e merecedor de igual respeito - é fundamental para uma virada democrática, bem como para o estabelecimento de um paradigma de alteridade que supere essas políticas e práticas opressoras contra os povos indígenas e demais grupos minoritários. Transpor esse contexto de tentativas de extermínio, que assola os povos indígenas desde o Período Colonial, exige a efetivação de direitos fundamentais básicos, condições para o exercício da cidadania, garantia de participação e de autonomia, promoção da igualdade com respeito às diferenças, a superação de discursos de dominação, enfim, exige enterrar um passado de exclusão e subalternização para germinar um futuro de igualdade e reconhecimento.

\section{Considerações finais}

A pandemia de Covid-19, ao lado de outros eventos, como a centenária gripe espanhola, produz graves cicatrizes na atual geração e na história da humanidade; e apesar de todos estarem suscetíveis, a vulnerabilidade se potencializa diante das realidades enfrentadas por determinados grupos sociais. Enquanto para uns a turbulência representa pequenas mudanças de navegação, para outros significa o "encalhamento" ou o "naufrágio". Historicamente dominados e marginalizados, os povos indígenas são um exemplo dessa vulnerabilidade deliberadamente potencializada por ações e omissões do Estado brasileiro. A condição socioeconômica, assim como a sensibilidade imunológica dessa minoria, exigem particular atenção dos poderes públicos e de toda sociedade. Todavia, o que ocorre é exatamente ao contrário.

O descaso do Estado com o direito fundamental à saúde indígena transparece a reprodução das mesmas atrocidades e violências praticadas desde o Período Colonial, evidenciando o desprezo, por essas culturas, por essas identidades, por essas pessoas. A falta de reconhecimento das diferenças culturais e identitárias, e a prevalência de uma racionalidade econômica violenta contribuem para o contexto de extermínio desses corpos. Com um olho no passado e o outro no presente, é possível observar que desde a colonização o Estado legitimou uma política de morte contra esses povos - uma necropolítica - marcando os corpos que podem-devem morrer, diretriz que encontra na pandemia de Covid-19 a sua consolidação com uma efetiva chance de extermínio de determinados povos.

Apesar de todo o arcabouço nacional e internacional de proteção aos direitos dos povos indígenas, esses grupos continuam sofrendo massivas violações que atentam contra suas existências. Nesse ponto, muito além de normas e previsões legais, é preciso trabalhar para uma virada democrática da realidade concreta e do imaginário social. Além da pandemia sanitária, e como o Brasil tampona os eventos traumáticos de sua história, vive-se um retorno do recalcado, um ressurgimento de discursos retrotópicos e de ódio, embalados em uma nostalgia que, expressa ou tacitamente, legitima a morte dos tachados de "inimigos", dentre os quais se tem como os vulneráveis de sempre e/ou outros imaginários. Esse contexto revela a importância do reconhecimento das diferenças identitárias e da construção de uma prática intercultural dos direitos humanos e fundamentais que reconheça a dignidade compartilhada por todos os seres humanos, acima de diferenças culturais ou identitárias. Navegar, com sabedoria, continua sendo necessário, para salvar vidas e ressignificar a história, durante e depois do atual eclipse! 


\section{Referências}

AGRA, Walber de Moura. Curso de direito constitucional. 9. ed. Belo Horizonte: Editora Fórum, 2018.

BRASIL. [Constituição (1891)]. Constituição da República dos Estados Unidos do Brasil de 1891. Brasília, DF: Presidência da República, [2020]. Disponível em: http://www.planalto.gov.br/ccivil_03/Constituicao/ Constituicao91.htm. Acesso em: 10 jul. 2020.

BRASIL. [Constituição (1934)]. Constituição da República dos Estados Unidos do Brasil de 1934. Brasília, DF: Presidência da República, [2020]. Disponível em: http://www.planalto.gov.br/ccivil_03/constituicao/ constituicao34.htm. Acesso em: 10 jul. 2020.

BRASIL. [Constituição (1946)]. Constituição dos Estados Unidos do Brasil de 1946. Brasília, DF: Presidência da República, [2020]. Disponível em: http://www.planalto.gov.br/ccivil_03/constituicao/constituicao46.htm. Acesso em: 10 jul. 2020.

BRASIL. [Constituição (1967)]. Constituição da República Federativa do Brasil de 1967. Brasília, DF: Presidência da República, [2020]. Disponível em: http://www.planalto.gov.br/ccivil_03/Constituicao/ Constituicao67.htm. Acesso em: 10 jul. 2020.

BRASIL. [Constituição (1988)]. Constituição da República Federativa do Brasil de 1988. Brasília, DF: Presidência da República, [2020]. Disponível em: http://www.planalto.gov.br/ccivil_03/constituicao/constituicao. htm. Acesso em: 10 jul. 2020.

BRASIL. Emenda Constitucional $n^{\circ} 1$, de 17 de outubro de 1969. Edita o novo texto da Constituição Federal de 24 de janeiro de 1967. Brasília, DF: Presidência da República, [2020] Disponível em: http://www.planalto. gov.br/ccivil_03/Constituicao/Emendas/Emc_anterior1988/emc01-69.htm. Acesso em: 10 jul. 2020.

BRASIL. Lei ${ }^{\circ}$ 601, de 18 de setembro de 1850. Dispõe sobre as terras devolutas do Império. Brasília, DF: Presidência da República, [2020]. Disponível em: http://www.planalto.gov.br/ccivil_03/LEIS/L0601-1850.htm. Acesso em: 10 jul. 2020.

BRASIL. Lei $\mathbf{n}^{\circ}$ 9.836, de 23 de setembro de 1999. Acrescenta dispositivos à Lei $n^{\circ} 8.080$, de 19 de setembro de 1990, que "dispõe sobre as condições para a promoção, proteção e recuperação da saúde, a organização e o funcionamento dos serviços correspondentes e dá outras providências", instituindo o Subsistema de Atenção à Saúde Indígena. Brasília, DF: Presidência da República, [2020]. Disponível em: http://www.planalto.gov.br/ ccivil_03/leis/L9836.htm. Acesso em: 11 jul. 2020.

BUCHILLET, Dominique. Bibliografia crítica da saúde indígena no Brasil (1844-2006). Quito: Abya-Yala, 2007.

BUTLER, Judith. Quadros de guerra: quando a vida é passível de luto?. Rio de Janeiro: Civilização Brasileira, 2015.

CEPAL. Os povos indígenas na América Latina: avanços na última década e desafios pendentes para a garantia de seus direitos. Santiago: CEPAL, 2015. Disponível em: https://repositorio.cepal.org/bitstream/ handle/11362/37773/S1420764_pt.pdf?sequence=1\&isAllowed=y. Acesso em: 11 jul. 2020.

CIMI. Relatório violência contra os povos indígenas no Brasil: dados de 2018. [S.I.]: CIMI, 2018. Disponível em: https://cimi.org.br/wp-content/uploads/2019/09/relatorio-violencia-contra-os-povos-indigenas-brasil-2018. pdf. Acesso em: 15 jul. 2020.

CUNHA, Manuela Carneiro da. Os direitos do índio: ensaios e documentos. São Paulo: Editora Brasiliense, 1987.

CUNHA, Manuela Carneiro da. Introdução a uma história indígena. In: CUNHA, Manuela Carneiro da (org.). História dos índios no Brasil. 2. ed. São Paulo: Companhia das Letras: FAPESP: SMC, 1998. p. 9-24. 
DORNELLES, Ederson Nadir Pires; BRUM, Fabiano Prado de; VERONESE, Osmar. Indígenas no Brasil: (in) visibilidade social e jurídica. Curitiba: Juruá Editora, 2017.

DUSSEL, Enrique. 1492 - O encobrimento do outro: a origem do mito da modernidade. Conferências de Frankfurt/Enrique Dussel. Tradução: Jaime A. Classen. Petrópolis: Editora Vozes, 1993.

FERRAJOLI. Luigi. Poderes selvagens: a crise da democracia italiana. Tradução: Alexander Araujo de Souza. São Paulo: Saraiva, 2014.

FERREIRA, Luciane Ouriques. Relatório técnico contendo análise dos Protocolos e Normativas do Ministério da Saúde e da Secretaria Especial de Atenção à Saúde Indígena (SESAI/MS) para o enfrentamento da COVID-19 junto aos povos indígenas. Cuiabá: OPAN, 2020. Disponível em: https:// amazonianativa.org.br/wp-content/uploads/2020/05/RELATORIO_TECNICO_1_OPAN_Saude_mai2020.pdf. Acesso em: 12 jul. 2020.

FIOCRUZ. Risco de espalhamento da COVID-19 em populações indígenas: considerações preliminares sobre vulnerabilidade geográfica e sociodemográfica. Rio de Janeiro: Fiocruz, 2020. Disponível em: https:// portal.fiocruz.br/sites/portal.fiocruz.br/files/documentos/relatorios_tecnicos_-_covid-19_procc-emap-ensp-covid19-report4_20200419-indigenas.pdf. Acesso em: 14 jul. 2020.

FILAC. Los pueblos indígenas ante la pandemia del Covid-19. La Paz: Filac, 2020. Disponível em: https:// indigenascovid19.red/wp-content/uploads/2020/05/FILAC_FIAY_primer-informe-PI_COVID19.pdf. Acesso em: 12 jul. 2020.

FOUCAULT, Michel. História da sexualidade I: a vontade de saber. Tradução: Maria Thereza da Costa Albuquerque, J. A. Guilhon Albuquerque. 13. ed. Rio de Janeiro: Edições Graal, 1999.

FOUCAULT, Michel. Em defesa da sociedade. Tradução: Maria Ermantina Galvão. São Paulo: Martins Fontes, 2005.

GARNELO, Luiza. Política de Saúde Indígena no Brasil: notas sobre as tendências atuais do processo de implantação do subsistema de atenção à saúde. In: GARNELO, Luiza; PONTES, Ana Lúcia (org.). Saúde indígena: uma introdução ao tema. Brasília: MEC, 2012. p. 18-58. Disponível em: http://bvsms.saude.gov.br/ bvs/publicacoes/saude_indigena_uma_introducao_tema.pdf. Acesso em: 12 jul. 2020.

GOMES, Mércio Pereira. Os índios e o Brasil: passado, presente e futuro. São Paulo: Editora Contexto, 2012.

MBEMBE, Achille. Necropolítica: biopoder, soberania, estado de exceção, política da morte. Tradução: Renata Santini. São Paulo: n-1 Edições, 2018.

MENDES, Gilmar Ferreira; BRANCO, Paulo Gustavo Gonet. Curso de direito constitucional. 10. ed. São Paulo: Saraiva, 2015. (Série IDP)

OLIVEIRA, João Pacheco de; FREIRE, Carlos Augusto da Rocha. A presença indígena na formação do Brasil. Brasília: Ministério da Educação, 2006. Disponível em: http://www.dominiopublico.gov.br/download/texto/ me004372.pdf. Acesso em: 8 jul. 2020.

SANTOS, Boaventura de Sousa. A cruel pedagogia do vírus. Coimbra: Almedina, 2020.

SARLET, Ingo Wolfgang. A eficácia dos direitos fundamentais: uma teoria geral dos direitos fundamentais na perspectiva constitucional. 13. ed. Porto Alegre: Livraria do Advogado, 2018.

SOUZA FILHO, Carlos Frederico Marés de. Multiculturalismo e direitos coletivos. In: SANTOS, Boaventura de Sousa (org.). Reconhecer para libertar: os caminhos do cosmopolitismo multicultural. Rio de Janeiro: Civilização Brasileira, 2003. p. 71-109.

SOUZA FILHO, Carlos Frederico Marés de. 0 renascer dos povos indígenas para o direito. Curitiba: Juruá Editora, 2012. 
SOUZA FILHO, Carlos Frederico Marés de. Marco temporal e direitos coletivos. In: CUNHA, Manuela Carneiro da; BARBOSA, Samuel (org.). Direitos dos povos indígenas em disputa. São Paulo: Editora UNESP, 2018. p. 75-100.

SOUZA, Danigui Renigui Martins de. A biopolítica em Giorgio Agamben: estado de exceção, poder soberano, vida nua e campo. 2017. Dissertação (Mestrado em Filosofia) - Programa de Pós-Graduação em Filosofia, Universidade Federal do Rio Grande do Norte, Natal, 2017. Disponível em: https://repositorio.ufrn.br/jspui/ bitstream/123456789/22594/1/DaniguiReniguiMartinsDeSouza_DISSERT.pdf. Acesso em: 18 fev. 2021.

SILVA, José Afonso da. Parecer. In: CUNHA, Manuela Carneiro da; BARBOSA, Samuel (org.). Direitos dos povos indígenas em disputa. São Paulo: Editora UNESP, 2018. p. 17-42.

VERONESE, Luciane Gheller; VERONESE, Osmar. Saúde mental no Brasil: impasses e horizontes de uma política pública. Revista Direitos Culturais, Santo Ângelo, v. 12, n. 26, p. 75-90, jan./abr. 2017.

WARAT, Luis Alberto. A rua grita Dionísio!: direitos humanos da alteridade, surrealismo e cartografia.

Tradução: Vivian Alves de Assis, Júlio César Marcelino Jr., Alexandre Morais da Rosa. Rio de Janeiro: Lumen Juris, 2010.

Recebido em: 12.11 .2020

Aceito em: 24.08.2021 